\title{
The Relationship Of Knowledge And Attitude Of Mother's Breasfeeding With Exclusive Giving
}

\author{
Monifa Putri, Deni Listi \\ Prodi DIII Kebidanan, Akademi Kebidanan Indragiri, 29312 Rengat, Riau \\ Monifaputri030@gmail.com
}

\section{Article Info}

\section{Article history}

Received date: 2020-05-11

Revised date: 2020-07-24

Accepted date: 2020-7-27

\begin{abstract}
Breast milk (ASI) is the only food that is the best for babies, because it has the most complete nutritionalcomposition for baby's growth and development. Methode: this research is analytic using cross sectional approach. The sampling technique is by simple random sampling. Data analysis was performed using the Chi-Square test at a significance level of $p<0.05$. Result: the study showed that from 68 respondents the majority of knowledge of breastfeeding morthers with exclusive breastfeeding was well-informed 48 people $(70.6 \%)$ and the ChiSquare statistical test results obtained a $P$ value of $<0.05(P$. Value $=0.004)$. Breastfeeding with exclusive breastfeeding the majority of positive attitude 57 people $(83.8 \%)$ and the Chi-Square statistical test results obtained a value of $P<0.05$ ( $P$. Value $=0.008$ ). Conclusion: based on the results of the study showed a significant relationship between knowledge $(P$. Value $=0.004)$ and attitude $(P$. Value $=0.008$ ) towards exclusive breastfeeding.

Keywords:

Breastfeeding mothers, exclusive breastfeeding, knowledge, attitude.
\end{abstract}

\begin{abstract}
Abstrak
Air Susu lbu (ASI) merupakan satu-satunya makanan yang terbaik untuk bayi, karena memiliki komposisi gizi yang paling lengkap untuk pertumbuhan dan perkembangan bayi. Metode: Jenis penelitian ini adalah Deskriptif analitik dengan menggunakan pendekatan cross sectional. Teknik pengambilan sampel dengan cara simple random sampling. Analisa data dilakukan dengan menggunakan uji Chi-Square pada tingkat signifikansi $p<0,05$. Hasil: penelitian menunjukkan bahwa dari 68 responden mayoritas pengetahuan ibu menyusui dengan pemberian ASI eksklusif yaitu berpengetahuan baik 48 orang $(70,6 \%)$ dan hasil uji statistik Chi-Square didapatkan nilai $P<0,05$ (P. Value $=0,004)$. Sikap ibu menyusui dengan pemberian ASI eksklusif mayoritas bersikap positif 57 orang $(83,8 \%)$ dan hasil uji statistik Chi-Square didapatkan nilai $\mathrm{P}<0,05$ ( $\mathrm{P}$. Value $=0,008$ ). Kesimpulan: berdasarkan hasil penelitian menunjukkan ada hubungan bermakna antara pengetahuan ( $P$. Value $=0,004)$ dan sikap $(P$. Value $=0,008)$ terhadap pemberian ASI eksklusif.
\end{abstract}

Kata Kunci

Ibu menyusui, Pemberian ASI Eksklusif, Pengetahuan, Sikap

\section{PENDAHULUAN}

Setiap tahun di dunia ada sekitar 4 juta bayi meninggal kerena penyakit infeksi terkait dengan perilaku yang tidak memberikan colostrum dan Air Susu Ibu (ASI) eksklusif pada bayi. Pemberian ASI eksklusif merupakan salah satu program untuk menurunkan angka kematian neonatal. Pemberian ASI tengah merosot hampir diberbagai penjuru dunia. Hal ini kerena 
perilaku ibu yang mengesampingkan manfaat gizi dan imunologi ASI terhadap ibu dan bayinya [1].

WHO dan UNICEF merekomendasikan pada tahun 2010 di Janeva tentang makanan bayi dan anak antara lain, menyusu merupakan bagian terpadu dari proses produksi yang memberikan makanan bayi secara ideal dan alamiah serta merupakan dasar biologi psikologik yang dibutuhkan untuk pertumbuhan dan perkembangan bayi, tanpa memberikan susu formula sebagai tambahan atau dalil apapun pada bayi yang harus dihindari. Dalam rangka menurunkan angka kesakitan dan kematian anak, WHO dan UNICEF merekomendasikan sebaiknya anak hanya disusui Air Susu lbu (ASI) selama paling sedikit enam bulan, dan pemberian ASI dilanjutkan sampai anak berumur dua tahun [2].

Air Susu lbu (ASI) merupakan satu-satunya makanan yang terbaik untuk bayi, karena memiliki komposisi gizi yang paling lengkap untuk pertumbuhan dan perkembangan bayi. Melihat manfaat yang besar, maka pemberian ASI Eksklusif sangat dianjurkan. Maksud ASI Eksklusif disini adalah pemberian ASI selama 6 bulan tanpa makanan tambahan lain seperti susu formula, jeruk, madu, air teh, air putih dan makanan tambahan padat seperti pisang, pepaya, bubur susu, biskuit, bubur nasi, dan tim sejak lahir hingga bayi umur 6 bulan [3].

Pemberian ASI Eksklusif sendiri tidak dapat berjalan dengan baik jika tidak diimbangi dengan perilaku ibu, disamping perilaku ibu juga banyak faktor yang mempengaruhi ibu dalam memberikan ASI dan lamanya menyusui, diantaranya: budaya, lingkungan hidup, pendidikan ibu, dan perilaku ibu. Faktor sosial ekonomi juga menentukan keyakinan dan sikap, serta praktik ibu dalam memberikan ASI, untuk memutuskan memberikan ASI pada bayinya, juga dipengaruhi oleh sikap dan dukungan suami, anggota keluarga serta lingkungan sekitar.
Perilaku menyusui berkaitan dengan pengetahuan yang kurang, kepercayaan atau persepsi dan sikap yang salah dari ibu mengenai ASI, dukungan suami, keluarga, tenaga kesehatan dan masyarakat sangat diperlukan agar ibu dapat menyusui secara eksklusif. lbu sebagai bagian dalam keluarga memegang peranan sangat penting dalam upaya ini [4].

Data Riskesdas tahun 2018 menunjukkan bahwa proporsi pola pemberian ASI pada bayi umur 0-5 bulan di Indonesia sebanyak $37,3 \%$ ASI eksklusif, 9,3\% ASI parsial, dan $3,3 \%$ ASI predominan. Menyusui predominan adalah menyusui bayi tetapi pernah memberikan sedikit air atau minuman berbasis air misalnya teh, sebagai makanan/minuman prelakteal sebelum ASI keluar. Sedangkan menyusui parsial adalah menyusui bayi serta diberikan makanan buatan selain ASI seperti susu formula, bubur atau makanan lain sebelum bayi berusia 6 bulan, baik diberikan secara kontinyu maupun sebagai makanan prelakteal [5]. Persentase anak berumur di bawah 6 bulan yang mendapatkan ASI eksklusif meningkat dalam 5 lima terakhir, dari $42 \%$ pada SDKI 2012 menjadi 52\% pada SDKI 2017 [6].

Berdasarkan data yang diperolah dari kabupaten Indragiri Hulu cakupan ASI Eksklusif pada tahun 2014 berjumlah 56,7\%, dimana masih belum mencapai target Renstra Dinas Kesehatan Provinsi Riau yaitu $70 \%$ dan target Nasional yaitu $80 \%$. Kegagalan ASI eksklusif bisa disebabkan bermacam-macam faktor seperti pengetahuan ibu, budaya memberikan tambahan susu formula karena ASI tidak keluar, menghentikan pemberian ASI karena ibu sakit dan juga ibu keharusan untuk bekerja [7].

Penelitian ini bertujuan untuk mengetahui hubungan pengetahuan dan sikap ibu menyusui dengan pemberian ASI eksklusif di wilayah kerja Puskesmas Sipayung Rengat. 


\section{METODE}

Penelitian yang digunakan adalah metode yang bersifat analitik, yaitu penelitian yang mencoba menggali bagaimana dan mengapa fenomena kesehatan itu terjadi. Pendekatan yang digunakan pada penelitian ini adalah pendekatan Cross Sectional yaitu suatu penelitian yang mempelajari hubungan antara variabel bebas (independent) dengan variabel terikat (dependent), dimana melakukan observasi atau pengukuran variabel sekaligus pada waktu yang sama. Data yang berhubungan dengan variabel bebas (pengetahuan dan sikap) dan variabel terikat (pemberian ASI eksklusif). Teknik pengambilan sampel dengan cara simple random sampling. Penelitian ini dilakukan pada bulan November 2015-Januari 2016.

\section{HASIL DAN PEMBAHASAN}

Berdasarkan penelitian yang telah dilakukan di wilayah kerja Puskesmas Sipayung, dengan responden ibu menyusui berjumlah 68 responden, didapatkan hasil penelitian dalam bentuk univariat dan bivariat sebagai berikut:

\section{Analisis Univariat}

Pengetahuan responden: berdasarkan diagram 1 di bawah ini, diketahui bahwa responden ibu menyusui memiliki pengetahuan baik $70.6 \%$ lebih banyak dibandingkan pengetahuan kurang sebesar $29.4 \%$.

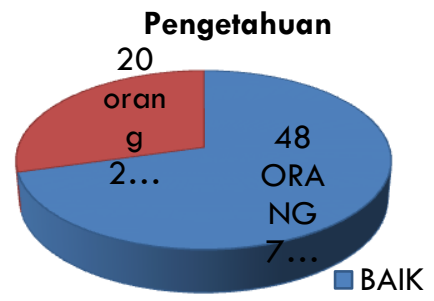

Diagram 1. Distribusi Frekuensi Pengetahuan Ibu menyusui Dengan Pemberian ASI Eksklusif Di Wilayah Kerja Puskesmas Sipayung.
Sikap responden: Berdasarkan Diagram 1 menunjukkan bahwa responden ibu menyusui memiliki sikap positif $83.8 \%$ dibandingkan yang memiliki sikap negatif sebesar $16.2 \%$.

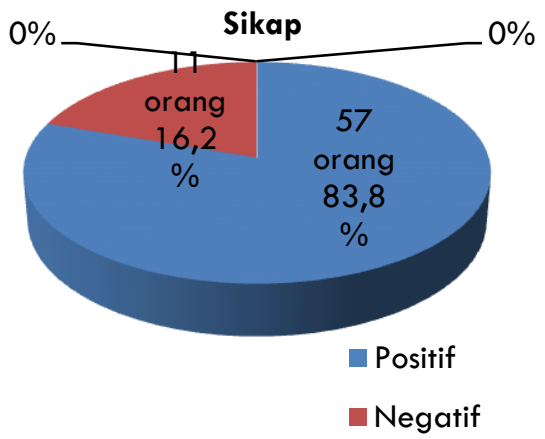

Diagram 2. Distribusi Frekuensi Sikap lbu Menyusui Terhadap Pemberian ASI Eksklusif Di Wilayah Kerja Puskesmas Sipayung.

Pemberian ASI eksklusif: Berdasarkan diagram 3 menunjukkan bahwa responden ibu menyusui yang memberikan ASI secara eksklusif yaitu 54 orang $(79,4 \%)$ dibandingkan tidak memberikan ASI secara eksklusif yaitu 14 orang $(20,4 \%)$.

Pemberian asi eksklusif

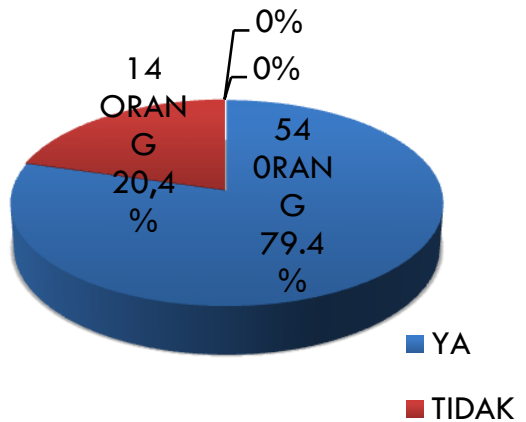

Diagram 3. Distribusi Frekuensi Pemberian ASI Eksklusif Yang Diberikan Ibu Menyusui Kepada Bayinya Di Wilayah Kerja Puskesmas Sipayung. 


\section{Analisis Bivariat}

Hubungan pengetahuan dengan pemberian ASI Eksklusif: hasil penelitian menunjukkan bahwa responden ibu menyusui berpengetahuan baik ternyata memberikan ASI eksklusif sebesar 63,2\% lebih banyak dibandingkan responden ibu menyusui yang berpengetahuan kurang memberikan ASI eksklusif sebesar 16,2\%.

Hasil Uji statistik Chi-Square didapatkan nilai $P<0,05(P=0,004)$, maka dapat disimpulkan bahwa ada hubungan yang bermakna antara pengetahuan dengan pemberian ASI eksklusif.

Tabel 1. Hubungan Pengetahuan lbu Menyusui dengan Pemberian ASI Eksklusif Di Wilayah Kerja Puskesmas Sipayung.

\begin{tabular}{|c|c|c|c|c|c|c|c|}
\hline \multirow{3}{*}{$\begin{array}{c}\text { Pengeta } \\
\text { huan }\end{array}$} & \multicolumn{4}{|c|}{ Pemberian ASI Ekslusif } & \multirow{2}{*}{\multicolumn{2}{|c|}{ Total }} & \multirow{3}{*}{ Pvalue } \\
\hline & \multicolumn{2}{|c|}{ Ya } & \multicolumn{2}{|c|}{ Tidak } & & & \\
\hline & $\mathrm{n}$ & $\%$ & $\mathrm{~N}$ & $\%$ & $\mathrm{n}$ & $\%$ & \\
\hline Baik & 43 & $\begin{array}{c}63 \\
2\end{array}$ & 5 & 7,4 & 48 & $\begin{array}{c}70, \\
6\end{array}$ & 0,004 \\
\hline Kurang & 11 & $\begin{array}{c}16 \\
2\end{array}$ & 9 & $\begin{array}{c}13 \\
2\end{array}$ & 20 & $\begin{array}{c}29 \\
4\end{array}$ & \\
\hline Total & 54 & $\begin{array}{l}79, \\
4\end{array}$ & 14 & $\begin{array}{c}20, \\
6\end{array}$ & 68 & $\begin{array}{c}10 \\
0\end{array}$ & \\
\hline
\end{tabular}

Hubungan Sikap dengan pemberian ASI Eksklusif: hasil penelitian menunjukkan bahwa responden ibu menyusui bersikap positif ternyata memberikan ASI eksklusif sebesar $72 \%$ lebih banyak dibandingkan responden ibu menyusui yang bersikap negatif memberikan ASI eksklusif sebesar $7,4 \%$.

Hasil Uji statistik Chi-Square didapatkan nilai $P<0,05(P=0,008)$, maka dapat disimpulkan bahwa ada hubungan yang bermakna antara sikap dengan pemberian ASI eksklusif.
Tabel 2. Hubungan Sikap lbu Menyusui dengan Pemberian ASI Eksklusif Di Wilayah Kerja Puskesmas Sipayung.

\begin{tabular}{|c|c|c|c|c|c|c|c|}
\hline \multirow{3}{*}{ Sikap } & \multicolumn{4}{|c|}{ Pemberian ASI Ekslusif } & \multirow[b]{3}{*}{$n$} & \multirow[b]{2}{*}{ Total } & \multirow[b]{3}{*}{$\begin{array}{c}\text { Pral } \\
\text { ue }\end{array}$} \\
\hline & \multicolumn{2}{|c|}{ Ya } & \multicolumn{2}{|c|}{ Tidak } & & & \\
\hline & $\mathrm{n}$ & $\%$ & $n$ & $\%$ & & $\%$ & \\
\hline Positif & 49 & 72 & 8 & 11,8 & 57 & 83,8 & \\
\hline & & & & & & & 0,00 \\
\hline Negatif & 5 & 7,4 & 6 & 8,8 & 11 & 16,2 & 8 \\
\hline Total & 54 & 79,4 & 14 & 20,6 & 68 & 100 & \\
\hline
\end{tabular}

\section{Hubungan pengetahuan}

dengan pemberian ASI Eksklusif

Hasil Uji statistik Chi-Square didapatkan nilai $\mathrm{P}<0,05(\mathrm{P}=0,004)$, maka dapat disimpulkan bahwa ada hubungan yang bermakna antara pengetahuan dengan pemberian ASI eksklusif.

Pengetahuan responden tentang ASI eksklusif berhubungan dengan pemberian ASI eksklusif karena pengetahuan responden yang baik tentang ASI eksklusif akan terwujud dalam tindakan pemberian ASI eksklusif dan dengan pengetahuan yang kurang akan membuat tindakan seseorang menjadi kurang baik. Menurut Kuncoroningrat makin tinggi pendidikan seseorang, makin mudah ia menerima informasi sehingga makin banyak pula pengetahuan yang dimiliki. Sebaliknya pendidikan yang kurang akan menghambat perkembangan sikap seseorang terhadap seseorang terhadap nilai-nilai yang baru diperkenalkan. Pengetahuan juga dipengaruhi: informasi (media massa), sosial budaya dan ekonomi, lingkungan dan juga pengalaman. Melalui pendidikan akan menutun manusia untuk berbuat dan mengisi kehidupan yang dapat digunakan untuk mendapatkan informasi sehingga dapat meningkatkan kualitas hidup. Hal ini dapat disimpulkan bahwa semakin tinggi pengetahuan seseorang tentang ASI maka akan menimbulkan perilaku positif memberikan memberikan ASI eksklusif. 
Rendahnya tingkat pengetahuan ibu tentang ASI menyebabkan ibu tidak memberikan ASI eksklusif kepada anaknya hal ini akan mempengaruhi status gizi bayi [8].

Hasil penelitian ini sejalan dengan penelitian Mariane W, dkk (2013), dengan judul Hubungan Pengetahuan dan Sikap dengan Pemberian ASI Eksklusif pada lbu Menyusui di Puskesmas Bahu Kota Manado. Setelah dilakukan uji statistik dengan menggunakan uji spearman's rho didapatkan hasil $\mathrm{p}=$ $0,000<0,05$. Sehingga ada hubungan pengetahuan dengan pemberian ASI eksklusif [9].

Hal ini juga sesuai dengan penelitian Nurleli, dkk (2017) yang berjudul Hubungan Pengetahuan dan Sikap lbu dengan Tindakan Pemberian ASI Eksklusif di Puskesmas Rambung Kecamatan Binjai Selatan Kota Binjai Tahun 2017. Hasil penelitian dengan menggunakan uji chisquare menunjukkan bahwa nilai $p=0,000$ $<0,05$, sehingga dapat disimpulkan bahwa pengetahuan memiliki hubungan signifikan dengan tindakan pemberian ASI eksklusif [10].

Namun hasil penelitian ini tidak sejalan dengan penelitian Nova $\mathrm{H}$ (2010), dengan judul Hubungan Pengetahuan dan Sikap lbu dengan Pemberian ASI Eksklusif pada Bayi Berusia 6-12 Bulan Di Wilayah Kerja Puskesmas Bailang Kota Manado. Hasil penelitiannya dari 99 responden mayoritas memiliki pengetahuan Baik, ibu yang memberikan ASI eksklusif sebanyak 29 orang $(29,3 \%)$ dan ibu yang tidak memberikan ASI eksklusif sebanyak 70orang (70,7\%), sedangkan dari 56 responden yang memiliki pengetahuan kurang, ibu yang memberikan ASI eksklusif sebanyak 45 orang $(80,4 \%)$. Berdasarkan hasil analisis dengan mengunakan chi-square menghasilkan probabilitas sebasar 0,259 jadi nilai probabitas lebih besar dari tingkat kesalahan 0.05, maka dinyatakan bahwa tidak terdapat hubungan antara kedua variabel antara variabel dependen dan independen. hasil ini menunjukkan bahwa banyak ibu yang bersikap kurang mendukung pemberian $\mathrm{ASI}$, hal ini dapat disebabkan karena pengaruh dari lingkungan sekitar. Lingkungan sekitar sangat mempengaruhi seseorang untuk mengambil keputusan yang terbaik. Karena pada saat ini semakin banyak promosi susu formula yang dianggap praktis bagi ibu [1 11$]$.

\section{Hubungan Sikap dengan pemberian ASI Eksklusif}

Hasil Uji statistik Chi-Square didapatkan nilai $P<0,05(P=0,008)$, maka dapat disimpulkan bahwa ada hubungan yang bermakna antara sikap dengan pemberian ASI eksklusif. Pengetahuan sangat berperan dalam membentuk sikap positif atau negatif seseorang. Tindakan pada kondisi pengetahuan yang baik adalah mendekati, menyenangi, mengharapkan obyek tertentu, sedangkan tindakan pada sikap negatif adalah menjauhi, menghindari, membenci, tidak menyukai obyek tertentu [8]. Sikap seseorang terhadap suatu obyek adalah perasaan mendukung atau memihak maupun perasaan tidak mendukung atau tidak memihak pada obyek secara spesifik [12]. Oleh karena itu, sikap ibu sebagian besar positif tentang ASI eksklusif dikarenakan pengetahuan ibu yang sudah baik. Selain itu, edukasi juga memberikan pengaruh terhadap perubahan sikap. Hal ini sesuai dengan hasil penelitian Alza Y, dkk (2016) dengan judul Pengaruh Edukasi Kesehatan Bagi lbu Hamil dan Keluarga Terhadap Praktek Inisiasi Menyusui Dini (IMD), ASI Eksklusif dan Peningkatan Berat Badan Bayi Sampai Berusia 1 Bulan di Wilayah Kerja Puskesmas Simpang Baru Kota Pekanbaru.bagi ibu hamil dan keluarga terhapa praktek IMD dan ASI eksklusif. Hasil uji statistik menunjukkan terdapat perbedaan signifikan terhadap sikap 
sebelum dan sesudah edukasi $(P<0,05)$ dengan tingkat kepercayaan $95 \%$. Hal ini menunjukkan bahwa edukasi memberikan pengaruh terhadap perubahan sikap bagi ibu hamil dan keluarga terhap praktek IMD dan ASI eksklusif [13].

Hasil penelitian ini sejalan dengan penelitian Triatmi A Y, dkk (2014), dengan judul Hubungan Pengetahuan dengan Sikap Ibu dalam Pemberian ASI Eksklusif di Wilayah Kerja Puskesmas Pranggang Kabupaten Kediri. Hasil penelitian dengan uji chi-square menyatakan bahwa nilai probabilitas sebesar 0,012<0,05. Hal ini berarti terdapat hubungan antara sikap terhadap ASI eksklusif pada ibu di wilayah kerja Puskesmas Tampaso Kecamatan Tampaso [14].

Begitu juga dengan hasil penelitian Fili $F$, dkk (2018) dengan judul Hubungan Pengetahuan, Sikap, dan Dukungan Suamu terhadap Pemberian ASI Eksklusif di Desa Pabuaran Kecamatan Gunung Sindur. Uji statistik menunjukkan hasil $\mathrm{p}$-value $=0,000$ $<0,05$, hal ini menyatakan bahwa ada hubungan antara sikap terhadap pemberian ASI eksklusif [15].

Hal ini juga sesusi dengan hasil penelitian lin D Y (2008) dengan judul Hubungan Pengetahuan dan Sikap lbu dengan Perilaku Pemberian ASI Eksklusif. Hasil uji statistik menunjukkan bahwa sikap ibu secara bermakna meningkatkan perilaku ASI eksklusif ( $p=0,006<0,005$ ) [16].

Namun hasil penelitian ini tidak sejalan dengan penelitian Nana Y, dkk (2013) dengan judul Hubungan antara Pengetahuan, Sikap dan Kepercayaan lbu dengan Pemberian ASI Eksklusif di Wilayah Kerja Puskesmas Bonto Cani Kabupaten Bone Tahun 2013. Hasil uji statistik menunjukkan bahwa tidak ada hubungan sikap dengan pemberian ASI eksklusif $(p=0,154>0,05)$ [17].

Sikap dapat terbentuk dari adanya interaksi sosial yang dialami individu. Interaksi disini tidak hanya berupa kontak sosial dan hubungan antar pribadi sebagai anggota kelompok sosial, tetapi juga meliputi juga hubungan dengan lingkungan fisik maupun lingkungan psikologis sekitarnya [18].

\section{SIMPULAN}

Responden ibu menyusui memiliki pengetahuan baik $70.6 \%$ lebih banyak dibandingkan pengetahuan kurang sebesar 29.4\%. Hasil Uji statistik Chi-Square didapatkan nilai $\mathrm{P}<0,05(\mathrm{P}=0,004)$, maka dapat disimpulkan bahwa ada hubungan yang bermakna antara pengetahuan dengan pemberian ASI eksklusif.

Responden ibu menyusui memiliki sikap positif $83.8 \%$ dibandingkan yang memiliki sikap negatif sebesar $16.2 \%$. Hasil Uji statistik Chi-Square didapatkan nilai $\mathrm{P}<0,05$ $(P=0,008)$, maka dapat disimpulkan bahwa ada hubungan yang bermakna antara sikap dengan pemberian ASI eksklusif.

\section{UCAPAN TERIMA KASIH}

Allhamdulillahirobbil'alamin, penulis dapat menyelesaikan penyusunan jurnal yang berjudul Hubungan Pengetahuan Dan Sikap Ibu Menyusui Dengan Pemberian Asi Eksklusif. Penulis menyadari jurnal ini tidak akan selesai tanpa bantuan berbagai pihak. Penulis mengucapkan terimakasih kepada Direktur Akademi Kebidanan Indragiri Rengat, LPPM dan Puskesmas Sipayung Rengat yang sudah memfasilitasi penelitian ini sehingga penulis dapat menyelesaikan jurnal ini.

\section{DAFTAR PUSTAKA}

[1] Arifah. Program ASI Eksklusif [Internet]. [cited 2015 Sep 10]. Available from: http://www.bps.go.id/abortus.com 
[2] World Health Organization. Pemberian ASI Eksklusif [Internet]. 2010. Available from: http:/www.who,int/.info

[3] Soetjuningsih.(1997). ASI Petujuk untuk Petugas Kesehatan. Jakarta: EGC

[4] Nurhuda F. (2012). Pengaruh Karakteristik (Pendidikan, Pekerjaan), Pengetahuan dan Slkap Ibu Menyusui terhadap Pemberian ASI Eksklusif di Kabupaten Tuban. Airlangga; Available from: repository.unair.ac.id

[5] Kementerian Kesehatan RI. (2018). Riskesdas. Jakarta

[6] Kementerian Kesehatan RI. (2018). Survei Demografi dan Kesehatan Indonesia. Jakarta

[7] Dinas Kesehatan Kabupaten Indragiri Hulu. (2016). Profil Dinas Kesehatan Kabupaten Indragiri Hulu. Kabupaten Indragiri Hulu

[8] Notoatmodjo. (2003). Pengetahuan, Sikap dan Prilaku Manusia. Jakarta: Infomedika

[9] Mariane W, Joice M. Laoh, Damajanty H.C. Pangemanan. Hubungan Pengetahuan dan Sikap dengan Pemberian ASI Eksklusif pada Ibu Menyusui di Puskesmas Bahu Kota Manado. J Keperawatan. Vol 1 No. 1.

[10] Nurleli, Jenny M. P., Rinawati S. (2016). Hubungan Pengetahuan dan Sikap lbu dengan Tindakan Pemberian
ASI Eksklusif di Puskesmas Rambung Kecamatan Binjai Selatan Kota Binjai Tahun 2017. J Ris Hesti Medan.Vol 3 No. 1.

[11] Nova H. (2010). Hubungan Pengetahuan dan Sikap lbu dengan Pemberian ASI Eksklusif pada Bayi Berusia 6-1 2 Bulan Di Wilayah Keria Puskesmas Bailang Kota Manado. Sam Ratulangi

[12] Azwar. (2011). Sikap Manusia Teori dan Penerapannya. Yogyakarta: Pustaka Belajar;.

[13] Alza, Y., Roziana, Fitriani. (2016). Pengaruh Edukasi Kesehatan Bagi lbu Hamil Dan Keluarga Terhadap Praktek Inisiasi Menyusu Dini (IMD), ASI Ekslusif Dan Peningkatan Berat Badan Bayi Sampai Berusia 1 Bulan Di Wilayah Kerja Puskesmas Simpang Baru Kota Pekanbaru. Jurnal Proteksi Kesehatan. Apr;5:13-26.

[14] Triatmi, A. Y., Dwi, E. R., Ekanana P. (2014). Hubungan Pengetahuan dengan Sikap lbu dalam Pemberian ASI Eksklusif di Wilayah Kerja Puskesmas Pranggang Kabupaten Kediri. Jurnal Ilmu Kesehatan ;Vol 3 No. 1.

[15] Fili F., Fenti D. P., Ichayuen A. (2018). Hubungan Pengetahuan, Sikap, dan Dukungan Suami terhadap Pemberian ASI Eksklusif di Desa Pabuaran Kecamatan Gunung Sindur. Hear J Kesehat Masy.; Vol 6 No. 1. 
[16] Yuliarti, I. D. (2008). Hubungan

Pengetahuan dan Sikap lbu dengan

Perilaku Pemberian ASI Eksklusif.

[Surakarta]: Sebelas Maret

[17] Yuliana, N., Burhanuddin B., Abdul, S.

(2013). Hubungan Antara

Pengetahuan, Sikap dan Kepercayaan

Ibu dengan Pemberian ASI Eksklusif di

Wilayah Kerja Puskesmas Bonto Cani

Kabupaten Bone Tahun 2013.

Available from:

http://repository.unhas.ac.id/bitstream

/handle/1 23456789/5560/JURNAL.

pdf

[18] A Wawan, Dewi M. (2008).Teori dan

Pengukuran Pengetahuan, Sikap dan

Perilaku Manusia. Yogyakarta: Nuha

Medika; 